Psychological Medicine, 1992, 22, 843-850. Copyright (C) 1992 Cambridge University Press

Printed in Great Britain

EDITORIAL

\title{
A comparison of French and British mental health legislation ${ }^{1}$
}

French psychiatry is known to be using quite different operational definitions of psychiatric syndromes (Kellam, 1989) from those used by English speaking doctors. Another way in which French psychiatry differs greatly in everyday practice is in its legal framework. In contrast with the intense activity in mental health legislation since World War II in Great Britain, the French psychiatrists continued to use the 1838 Statute until June 1990 when it was revised. At the time of its creation the 1838 Statute represented great progress allowing mentally ill patients to gain access to treatment for their disorders in specific and appropriate institutions (Quetel, 1988). Indeed, the first article of the 1838 Statute compelled each geographical département of France to have a psychiatric in-patient institution. These institutions were thought to be essential by Pinel in the promotion of his 'traitement moral' (Pinel, 1806). His disciple Esquirol played an important role in the elaboration of the 1838 Statute.

The two orders of the 1838 Statute, the placement d'office and the placement volontaire, reflected the theoretical ambiguity with which 'insanity' was considered in those times. On the one hand, mentally ill patients were considered to be dangerous individuals who needed detention in order to protect society. On the other hand, following Pinel's treatise they had also come to be considered as ill people whose illness was treatable and who deserved medical attention. It was some indication of progress that lunatics were no longer regarded in the same light as delinquents. Although they would be detained this would not be in the company of criminals.

It is remarkable that the 1838 Statute remained in force until 1990. In this article we will first define some legal terms necessary for the understanding of what will follow. We will then present a summary of the 1838 Statute of psychiatric legislation in France since it forms the basis of the 1990 Statute and this will be followed by a review of the 1990 Statute. We then comment on differences between the Mental Health Act (1983) of England and Wales (Bluglass, 1983) and the 1838 Statute. This is then followed by a discussion of the practical implications of the 1990 Statute for the patient, for his family and for the psychiatrist.

\section{DEFINITION OF SOME RELEVANT ADMINISTRATIVE LEGAL TERMS}

Commissaire de police

This is the person in immediate charge of the police in any town of 10000 or more (Thody \& Evans, 1985).

\section{Commissaire de la République}

It has recently been proposed that this term should replace the designation 'préfet'. However the word 'prefet' is still the expression used in the 1990 Statute (see below).

\section{Conseil général}

The assembly of conseillers généraux (county councillors) elected by direct local elections in each département. Le président du conseil general is elected by the conseillers généraux and has executive powers in the département, which until 1982 were entrusted to the préfet.

' Address for correspondence: Professor R. G. Priest, Academic Department of Psychiatry, St Mary's Hospital, Praed Street, London W2 INY. 


\section{Conseil municipal}

The assembly elected by direct general elections in each village or town. The maire is elected by the conseillers municipaux (town councillors) and there is one maire for 2500 inhabitants.

Cour d'appel (Court of appeal)

Pronounces judgements in the appeals against the decisions of the tribunal de grande instance. It is also composed of a président and juges (all magistrates).

\section{Département}

A unit of local government and decentralized administration, established at the time of the French Revolution. There are now 95 in France.

La commission départementale des hospitalisations psychiatriques (The commission on

psychiatric admissions for the department)

This is a new creation of the 1990 Statute. It is an advisory committee composed of two psychiatrists, a magistrate, and a representative of patients' families. It meets twice a year and is consulted by the prefet. It is to review the situation of in-patients, particularly with respect to civil liberties, amongst other duties (see below).

\section{Préfet}

The prefet is a senior civil servant who represents the authority of the State in a département. He is recommended to the President of France by le Ministère de IIntérieur (Home Office) and then nominated by the President. He has administrative powers and normally also supervises the police. However, in Paris and several large towns there are two préfets; one has administrative duties, the other one is the Préfet de Police.

Procureur de la République (Public Prosecutor)

A magistrate of the tribunal de grande instance representing the interests of the State.

Procureur général (Chief Prosecution Counsel for the State)

Unlike the other magistrates, the Procureurs are not independent from the State and they can be moved to another post by an administrative decision. They are appointed by the Ministry of Justice.

Tribunal de grande instance (High Court)

The common law court of second degree which is composed of a président and several juges (all magistrates).

\section{SUMMARY OF THE 1838 STATUTE}

There were only two methods of admission permitted under the 1838 Statute and both were compulsory detentions: the Placement Volontaire and the Placement d'Office (Goumilloux, 1981; Ferrey, 1986).

\section{The Placement Volontaire}

Despite the somewhat misleading title, this provision entailed the compulsory admission of a mentally disordered patient who refused the care necessary for his abnormal mental state, at the request of his relatives (mental disorder is not defined).

The formalities comprised: a written request for admission signed by a relative or close acquaintance of the patient; and one medical certificate (although its absence was not an insuperable obstacle to admission).

After 24 hours and after a further 2 weeks a psychiatrist from the admitting institution had to 
furnish to the Préfet a medical certificate confirming or otherwise the need for detention. There was no maximum period of detention, but the psychiatrist was required to write a monthly note on the progress of the patient in a register. The admission could be terminated either by the relatives or by the psychiatrist. The psychiatrist could override the relatives' decision only if the patient was deemed dangerous to others, in which case the psychiatrist could apply to the Préfet for a Placement rOffice.

\section{The Placement d'Office}

This was applied to patients whose mental state endangered public order or the safety of others. The formalities comprised: an application by Commissaires de police in Paris or Maires elsewhere; and one medical certificate (but its presence in cases of emergency was not an absolute requirement).

Again there was no maximum period of detention and the responsible medical officer had to send a monthly report to the Préfet regarding the patient's progress. The decision to rescind the order lay in the hands of the Prefet.

\section{Patients' rights}

The 1838 Statute made provision for measures to protect all the detained patients.

1. At the time of his 6-monthly visits to the psychiatric establishment, the procureur received the appeals of the detainees.

2. Patients were allowed to write freely to the judicial and administrative authorities.

3. Any patient, friend, or relative could appear before the court which, after an enquiry, could order an immediate discharge.

\section{REVIEW OF THE 1990 STATUTE}

The general aim of this new psychiatric legislation is to reinforce the protection of civil liberties of psychiatric patients (Caroli, 1990; Roy, 1990). There are still only two types of compulsory admission. The most important provisions are as follows.

\section{Hospitalisation sur demande d'un tiers (HDT)}

The Placement Volontaire, whose name was misleading, is now called Hospitalisation sur demande d'un tiers (HDT) - admission at the request of a third party. It applies to mentally disordered patients (mental disorder is still not defined) whose mental disorder renders them unable to consent to treatment. In addition their mental state is such as to require immediate treatment and constant monitoring as an in-patient.

The formalities for admission are: $(a)$ a written request by a relative or a person acting in the interest of the patient; $(b)$ a first medical certificate by a doctor who does not work in the admitting institution; and $(c)$ a second medical certificate by a doctor who may belong to the admitting institution. In the case of absolute emergency only one medical certificate $(b$ or $c)$ is required. Neither of these two doctors has to be a psychiatrist.

After 24 hours and after 15 days a psychiatrist who works in the institution has to write a medical certificate to confirm or otherwise the need for continued detention. A monthly medical certificate is then required. These medical certificates are transmitted to: the director of the hospital; the Préfet; the Commission départementale des hospitalisations psychiatriques; and the procureur de la république.

Failure to provide these certificates in due time leads to an automatic termination of the detention. This omission should not be deliberately used as a way of discharging the patient and to do so is in fact a punishable offence.

The doctors who sign the admission certificates should not be related by marriage or up to the fourth degree inclusive to either: the director of the hospital; the person who requests the admission; the patient; or the doctor who signs the other admission certificate. 
The admission can be terminated by the following persons: the responsible medical officer; the relatives; the person who signed the request for admission; the commission départementale des hospitalisations psychiatriques; or the prefet.

As in the 1838 Statute, the responsible medical officer can override the family's decision to discharge the patient only if he thinks the patient is dangerous to others. The responsible medical officer can then apply to the préfet for an Hospitalisation d'Office.

\section{Hospitalisation d'Office (HO)}

The Placement dOffice is renamed Hospitalisation d'Office $(\mathrm{HO})$. Under the $\mathrm{HO}$, the criteria for admission are identical to those of the 1838 Placement d Office, i.e. the mental state of the patient endangers public order and the safety of others.

The provisions are as follows: $(a)$ the same authorities as in the 1838 Statute take the decision to admit: the préfet de police in Paris and the prefets elsewhere and in the case of emergency the commissaire de police in Paris and the maires elsewhere; $(b)$ a medical certificate written by a doctor who does not work in the admitting institution. In case of emergency this certificate is not absolutely required and the $\mathrm{HO}$ is then valid for only 48 hours during which time the préfet is informed and takes the decision in favour of $\mathrm{HO}$ or otherwise.

After 24 hours, 15 days, and 1 month following the admission and monthly thereafter, the responsible medical officer produces medical certificates (for the prefet and the commission) on the progress of the patient. The préfet has to made his decision known after one month, 4 months, and then 6 monthly as to whether the detention is to continue. If the préfet omits to do so, the detention is terminated.

The responsible medical officer and the commission can recommend that the $\mathrm{HO}$ is rescinded but the final decision lies in the hands of the préfet who can discharge the patient at any time (see Table 1). The préfet's permission is also needed for temporary leave for the patients.

Table 1. Compulsory admission procedures in France under the 1990 Statute

\begin{tabular}{|c|c|c|}
\hline Sections & $\begin{array}{c}\text { HDT: hospitalisation sur demande } \\
\text { dun tiers }\end{array}$ & HO: hospitalisaton doffice \\
\hline $\begin{array}{l}\text { Criteria for } \\
\text { admission }\end{array}$ & $\begin{array}{l}\text { Mental disorder rendering a person, } \\
\text { who requires immediate in-patient } \\
\text { psychiatric treatment, unable to } \\
\text { consent }\end{array}$ & $\begin{array}{l}\text { Person whose mental state } \\
\text { endangers public order and } \\
\text { the safety of others }\end{array}$ \\
\hline $\begin{array}{l}\text { Formalities of } \\
\text { admission }\end{array}$ & Nearest relative and two doctors & Préfet and one doctor \\
\hline $\begin{array}{l}\text { Site where section } \\
\text { is applied (public } \\
\text { place, ward, casualty, } \\
\text { etc.) }\end{array}$ & No specific site & No specific site \\
\hline Duration of detention & $\begin{array}{l}24 \text { hours, } 15 \text { days, then monthly } \\
\text { medical certificates by responsible } \\
\text { psychiatrist reviewing the need for } \\
\text { detention }\end{array}$ & $\begin{array}{l}24 \text { hours, } 15 \text { days, then } \\
\text { monthly, medical certificates } \\
\text { by the responsible } \\
\text { psychiatrist }\end{array}$ \\
\hline $\begin{array}{l}\text { Usual manner of } \\
\text { termination }\end{array}$ & $\begin{array}{l}\text { Nearest relative or } \\
\text { responsible psychiatrist }\end{array}$ & $\begin{array}{l}\text { The prefet reviews the need for } \\
\text { detention after } 1 \text { month. } 4 \\
\text { months, then } 6 \text { monthly. The } \\
\text { prefet can also discharge the } \\
\text { patient at any time }\end{array}$ \\
\hline Appeal procedures & $\begin{array}{l}\text { Patients, relative or any person acting in } \\
\text { appear before the court who, after an }\end{array}$ & $\begin{array}{l}\text { e best interest of the patient can } \\
\text { uiry, can order an immediate discharge }\end{array}$ \\
\hline
\end{tabular}

\section{The situation of mentally abnormal offenders}

When a mentally abnormal offender has been acquitted but is deemed by the judicial authorities still to be potentially dangerous to others, they inform the prefet. The latter requests a psychiatric 
opinion and may order an HO. This HO differs from usual in the way that it is terminated. The prefet has to take the opinion of two approved psychiatric experts who do not work in the admitting institution. These two experts examine the patient separately and have to agree that the patient is no longer dangerous to himself or others.

When mentally abnormal offenders do not qualify for an HO, any other psychiatric disposal may be used, e.g. HDT, informal admission, or out-patient follow-up.

\section{The commission départmentale des hospitalisations psychiatriques}

This is a new feature of French psychiatric legislation. Its general role is to prevent illegal interferences with individual liberties.

This commission is composed of : a psychiatrist designated by the procureur général près la cour dappel; a magistrate designated by the président de la cour d'appel; a psychiatrist and a representative of an organization of relatives of mentally disordered patients. One of them is designated by the préfet, the other by the président du conseil général. Only one of the two psychiatrists may belong to the admitting institution.

The functions of the commission are as follows.

1. The commission is informed of any compulsory admission, renewal, and discharge.

2. The commission establishes each year a review of the emergency use of HDT and HO.

3. It examines, where necessary, the situation of detained patients and that of all patients in HDT for more than 3 months.

4. It can refer the situation of a detainee to the préfet or to the procureur de la république if necessary.

5. It visits the psychiatric institutions authorized (by the préfet) to care for detained patients and receives the appeals of the detainees.

6. It produces a yearly report for the prefet, the procureur de la république, and the conseil départemental de santé mentale.

7. It can recommend a patient's discharge to the président du tribunal de grande instance.

\section{Patients' rights and appeal procedures}

This aspect is an important concern of the 1990 Statute. Detained patients are to be informed of their legal situation and rights when admitted. They are allowed to: communicate with administrative and legal authorities; refer matters to the commission; ask for the advice of a lawyer or doctor of their choice; send or receive post ; receive explanations about the hospital regulations; vote; practice any religion. For both HDT and HO any patient, relative, or person who is acting in the best interests of the patient can appear before the président du tribunal de grande instance who, after an enquiry, can order an immediate discharge.

The préfet, the juge du tribunal de grande instance, the président du tribunal de grande instance, the maire are to visit the psychiatric institutions 6 monthly and the procureur de la République 3 monthly. During their visits the above authorities will receive the appeals of the patients.

The commission is to visit the institutions (the frequency is not specified) and look into the situation of every patient on HDT for more than 3 months.

\section{COMPARISON WITH THE ENGLISH MENTAL HEALTH ACT}

After this summary of the 1990 Statute in France we can now outline the main differences between this and the 1983 Mental Health Act of England and Wales.

1. The 1990 Statute, although more complex than the 1838 one, is still strikingly more simple than the 1983 Mental Health Act (MHA 1983). There are only two types of compulsory detention which apply to mentally disordered patients and offenders. The Hospitalisation sur Demande d'un Tiers (HDT) can be considered to be equivalent to the sections 2, 3, 4, 5(2), and the Hospitalisation dOffice (HO) to all the sections related to mentally abnormal offenders.

It is important to note that there are no sections specifically designed for mentally abnormal 
offenders. The HO, which is the closest to the English sections for mentally abnormal offenders can also be used for non-offenders. The patients for whom HO applies are deemed to be dangerous to others but have not necessarily done anything dangerous yet, so that a psychiatric patient who has not committed an offence can still, in the French system, find himself detained under the authority of the préfet.

Mental disorder is not further defined in the Statute and since it is the only descriptive term used to identify a psychiatric condition, no differentiation between mental disorder, illness or impairment is introduced, in contrast to the MHA 1983. From a clinical point of view the difference between the two types of detention in the French statute is that: one (HO) is specifically for patients whose mental state endangers public order or the safety of others; the other (HDT) is for mentally disordered patients whose mental state renders them unable to provide a valid consent to in-patient treatment.

There is no explicit allusion to risk of harm to self as a criterion for compulsory admission. The only reference made to harm to self is, rather unexpectedly, for the discharge of mentally abnormal offenders in HO. The two psychiatric experts, asked by the prefet to examine the patient before he can discharge him, are to write in their conclusions that the patient is no longer dangerous to self or others.

In the case of a patient detainable or detained in HDT, if the family forbids the admission of the patient or wants to discharge him, the family takes full responsibility for their relative. When there is a serious risk of harm to the self, the psychiatrist can only warn the family but cannot override the family's decision. As mentioned earlier, the doctor can overrule the family on this matter only if there is a risk of harm to others.

2. A major difference between the 1838 Statute and the MHA was the non-existence of a maximum period of detention in the French Statute. This has changed with the 1990 Statute. For the HDT the medical decision to continue in-patient treatment has to be reviewed after 24 hours, then 15 days, and then monthly. The French Statute does not have different 'sections' depending on the length of their validity.

For the HO the decision to discharge the patient lies in the hands of the prefet who has to review the detention after 1 month, then 4 months, then 6 months and thereafter 6 monthly. In both HDT and $\mathrm{HO}$ the detention can of course be terminated at any time before these reviews, if appropriate.

3. Any medical practitioner, whether psychiatrist or not, can sign the medical certificate either for HDT or for HO. In the case of an emergency only one medical certificate is required for HDT and none for HO. An approximate equivalent to the section 12 approved doctor requirement comes into question only 24 hours after the patient is admitted, in order to confirm or refute the necessity for compulsory admission.

4. There is no equivalent of the Approved Social Worker in France. It would be possible to ask a social worker to sign a request for HDT if one were not able to contact the family or the entourage of the patient. In fact, it is probable that a social worker would agree to do this only rarely.

5. Consent to treatment forms part of the 'Code of Practice for Medical Practitioners' rather than of the 1990 Statute. Psychiatric patients are not regarded as a special case in this respect. In theory, treatment can be given to a patient only if he is able to give valid consent. In practice, a psychiatrist will use his judgement and good faith and treat an informal or detained patient (possibly against his will) until the patient becomes capable of giving valid consent.

In the case of ECT, where a patient refuses the treatment or is unable to give valid consent, a consent form signed by the nearest relative will suffice.

6. Since the 1990 Statute the patients are to be informed of their situation and rights. Both for HDT and for HO any patient, relative or person acting in the interest of the patient can appear before the président du tribunal de grande instance who, after an enquiry, can order immediate discharge.

There is no real equivalent to Mental Health Review Tribunals. The Commission Départementale des Hospitalisations Psychiatriques is a creation of the 1990 Statute. It will probably take some time before its role can be assessed. In theory, it has broadly similar roles to the Mental Health Act 
Commission except for the appointment of doctors providing a second opinion on treatment, since this procedure has no equivalent in the French Statute.

\section{DISCUSSION}

We will now attempt to point out some of the advantages and disadvantages of the 1990 Statute for the family of the patient, the patient himself and the psychiatrist.

The family of the patient plays a very important role in the decision to admit their mentally disordered relative. The request for admission signed by a member of the family is the most important document in the HDT. Indeed, when the 1838 Statute was still in use, in a case of emergency it was the only relevant paper required. Thus, when the family initiates the request for admission, one can say that in practice the doctor's task is to confirm that it is a 'reasonable' demand. When the family is asked by a doctor to sign a request for admission, the family can refuse and take full responsibility for the patient's care unless he is thought to be dangerous to others. In that case the doctor would apply to the préfet for an HO. The family can also discharge a patient on HDT at any time, unless again the patient is thought to be dangerous to others. For patients who have recurrent relapses and who have little insight, their family can play an active role in management, requesting an HDT if they refuse care. This appears particularly relevant at the present day when community care is favoured and more pressure is put on families to care for the patients at home - who, other than the family, is so aware of the patient's needs? In the authors' experience, many relatives in England have felt unsupported when they have requested admission from doctors only to be told that the patient is 'not yet sectionable'. In France families are more likely to feel that their voices are heard and that they are able to obtain treatment for their sick relative more readily.

It is debatable whether it is in the interests of the patient that the family should be involved in such a direct fashion in psychiatric management. However, we consider that it is certainly in his interest that he should be treated at an early stage of the relapse of a severe mental illness even if this needs to be done compulsorily. The price to be paid by the patient is the reduction of his individual liberty, but it would be argued that untreated psychosis restricts individual liberty even more and may indeed result in over-representation of the psychiatrically ill in the prison system (Taylor \& Gunn, 1984).

It is remarkable that until recently only one doctor (i.e. any medical practitioner) was needed to sign the compulsory orders. The 1990 Statute has made a step in the direction of the 1983 MHA in that two doctors are to sign the compulsory orders. Some French doctors will perceive this as an infringement of their independence and authority. Even now they are not expected to share their medical responsibility with any other professional body as English psychiatrists do with approved social workers. A possible advantage for the psychiatrist working in England and Wales is that the social aspects are dealt with from the start by the social worker whereas in France they are mostly dealt with by the psychiatrists themselves. This is in keeping with the wider scope of French psychiatric practice where psychiatrists do not try to limit their intervention to mentally ill persons and are happy to deal with a wide range of psychological problems.

For future studies, it would be instructive to compare, using clinical illustrations, the differences in the day-to-day management of the patient resulting from the use of the 1838 Statue on the one hand and the 1983 Mental Health Act on the other.

I. LAFFONT AND R. G. PRIEST

We are grateful to Dr H. Grivois, Chef du Service de Psychiatrie, Hôtel-Dieu, Paris, and to Dr T. Bonnet, Psychiatre des Hôpitaux, Centre Hospitalier des Murets, 94510 La Queue en Brie, for their cooperation. We should also like to thank Dr I. Treasaden and Dr J. Steinert, consultant psychiatrists in London, for their helpful advice. 


\section{REFERENCES}

Bluglass, R. (1983). A Guide to the Mental Health Act 1983. Churchill Livingstone: Edinburgh.

Code de la Santé Publique, de la famille et de Taide sociale. (Loi du 30 Juin 1838, articles L326 to L355). Annale 4 - Code de déontologie médicale. Editions Dalloz, Paris. 1985 révision.

Caroli, F. (1990). La nouvelle loi est arrivée, est applicable... et appliquee. Echanges No. 49 (Journal dinformation du centre hospitalier Sainte-Anne).

Ferrey, G. (1986). Le médecin hospitalier et le placement volontaire en psychiatrie. Le Concours Médical 107, 349-351.

Goumilloux, R. (1981). Abrégé de Législation Psychiatrique. Editions Masson: Paris.

Kellam, A. M. P. (1989). French empirical criteria for the diagnosis of non-affective non-organic psychoses. British Journal of Psychiatry 155, 153-159.
Loi No. 90-527 du 27 juin 1990. Journal Officiel de la Rípublique Française du 30 juin 1990.

Pinel, P. (1806). A Treatise on Insanity (translated by D. D. Davis), Cadell \& Davies: Sheffield. (Reprinted 1962, Häfner: New York.) Quetel, C. (1988). La Loi de 1838 sur les Alicin's. Editions Frénesie: Paris.

Roy, P. (1990). Hospitalisation psychiatrique: la loi de 1838 est morte, la loi de 1990 impose de nouvelles règles. Le Quotidien du Médecin No. 4562.

Taylor, P. J. \& Gunn, J. (1984). Violence and psychosis. Risk of violence among psychotic men. British Medical Journal 288, 1945-1948.

Thody, P. \& Evans, H. (1985). Faux Amis and Key Words. Athlone Press: London. 